\title{
A BIZTONSÁG ÉRTÉKE ÉS ÁRA
}

\author{
Dr. Prof. Hima Gabriella egyetemi tanár
}

Művészeti anyanyelvi nevelési tanszék, Pedagógusképző Kar, NJE

\begin{abstract}
Kulcsszavak:
kiszámíthatatlan világ, biztonsági vágy, szabadságvesztés, a mérhetőség, a biztonság ökonómiája
\end{abstract}

Keywords:

incalculable world, safety desire, imprisonment, quantifiability, the economy of safety

\section{Összefoglalás}

A tanulmány a biztonság (safety) filozófiai és szociológiai aspektusait valamint az ennek hátterét képező közbiztonság (security) ökonómiai vonatkozásait vizsgálja. Bár a (poszt) modern kor ökológiai katasztrófái és terrorcselekményei nem tekinthetók a biztonságról folyó közéleti viták fó okainak, tény, hogy a 20-21. század fordulójától kezdve a fenyegetettség érzetének növekedésével a biztonság iránti vágyunk egyenes arányban növekszik. Ez a vágy, persze, nem újkeletü: mint elemi antropológiai szükséglet az emberiséggel egyidôs. A politikai retorika az ókori római szónokoktól kezdve a modern államvezetésekig mindig is operált ezzel a fogalommal, gyakran manipulatív célokra használva azt. A biztonságot középpontba helyező politikai kampányok éppúgy az ősi, zsigeri eredetü halálfélelmet célozzák meg, mint a mágiák és rítusok, kezdve az ősi hiedelmektől és babonáktól a vallásokig. A biztonságra a legtöbb nyelvben - így a magyarban is - egy szó van, az angolban kettö, melyek a biztonság két aspektusát testesítik meg: a safety a cél, a security pedig az eszköz a cél eléréséhez. A safety olyan cél, amelyröl tudjuk, hogy elérhetetlen, mégis vágyunk rá, olyan utópia, mint a modern európai társadalmak egyéb értékfogalmai (szabadság, egyenlőség, igazságosság). A biztonság (safety) nem vásárolható meg, azonban sokat tehetünk a saját biztonságunkért és a közbiztonságért (security), amelynek nemcsak eszmei, hanem materiális értéke, azaz ára van. A security ebben az értelemben nem más, mint a filozófiai-szociológiai értelemben felfogott safety közgazdasági aspektusa.

\section{Abstract}

This paper highlights the philosophical and sociological aspects of safety and the economic aspects of security. Although catastrophic potential inherent in (post-)modern risks is not the main cause of the rise of security debates nowadays, these have only gone viral as universal societal problems in the late $20^{\text {th }}$ and the early $21^{\text {st }}$ centuries. Actually, political discourse has always operated with the safety concept from the Roman rhetors to modern state leadership, often using it for manipulative purposes. Security-focused policy campaigns target the ancient, visceral fear of deaths like magic, rites, and religions providing false promises to satisfy our desire for safety. However, this desire shares the utopian character with such notions like freedom, equality or justice: all of them are unattainable. No government or institution can guarantee our safety but our security. While safety is a public or private good which is not for sale as it only has an ideal value, security is a common ware which has its price. Security is the economic aspect of safety. It is a commonplace that safety is costly, but lack of safety could be even more costly. Measuring costs of lacking safety and willingness-to-pay for security measures are crucial for the economic aspects of safety.

Arnold Gehlen német szociológus definíciója az emberról, mint állandó rizikóknak kitett lényről („riskiertes Wesen”), aktuálisabb, mint valaha. A jövőről szóló filozófiai és politikai szcenáriók szerint új, kontrollálhatatlan és kiszámíthatatlan civilizációs kockázatok fenyegetik világunkat. A régi, egyenlőtlen elosztásból és hatalmi viszonyból származó konfliktusokhoz újabb, ez idáig ismeretlen konfliktusok társulnak. A technikai vívmányok, 
például, nemcsak biztonságot nyújtanak, nemcsak komfortunkat szolgálják, hanem előreláthatatlan ökológiai katasztrófákkal fenyegetnek. Az erősödő fenyegetettség növeli a biztonság iránti vágyunkat. $\mathrm{Ez}$ a vágy, persze, nem napjainkban keletkezett, mint antropológiai szükséglet az emberiséggel egyidős. A külső és belső feszültségek egyensúlyára, az egyén helyzetének stabilizálására való törekvés minden korban fontos szerepet játszott, ezért annak tematizálása korán megjelent a civilizáció történetében. A politikai retorika az ókori római szónokoktól kezdve a modern államvezetésekig mindig is operált ezzel a fogalommal, gyakran manipulatív célokra használva azt. Amilyen atavisztikus ugyanis a biztonság iránti vágyunk, éppolyan hamis kielégíthetőségének politikai ígérete. A biztonságot középpontba helyező politikai kampányok éppúgy az ősi, zsigeri eredetű halálfélelmet célozzák meg, mint a mágiák és rítusok, kezdve az ősi hiedelmektől és babonáktól a vallásokig.

A filozófia par excellence tárgya halandóság és biztonság ontológiai viszonya. Ez a téma az Isten halálát deklaráló nietzschei tézis után - a szekuláris világkép elterjedésével uralja a nyugati kultúrkör gondolkodását. A transzcendenciába vetett hittel az ontológiai biztonság is elvész. A biztonság fogalmát kritikai vizsgálatnak alávető újabb monográfiák szerzői a heideggeri, sartre-i, camus-i mortalitás-elméleteket a haláltudat szociológiai elemzéseivel kombinálják, bizonyítva, hogy az újkori társadalmakban megteremtett jólét féltésével egyenes arányban nő a biztonságra való igény. Az Isten bizonyosságát nélkülöző „human condition” feltételei között a biztonság a halálfélelemre adható önszuggesztív, utópikus válasz.

Ezt fogalmazta meg a svájci szociológus, Franz-Xavér Kaufmann a biztonság, mint szociológiai és politikai probléma. Erösen differenciált társadalmak egyik értékeszményének vizsgálata címü 1970-ben megjelent, majd 2012-ben változatlan aktualitása miatt változatlan utánnyomásban újra kiadott habilitációs értekezésében. Ennek központi hipotézise, hogy az erősen differenciált újkori társadalmak nagyobb értéket tulajdonítanak a biztonságnak, mint a történetileg korábbi, kevésbé sztratifikált közösségek. A 20. század első felének két világháborúja utáni konszolidáció megnyugvást keltett, legalábbis a fehér emberi civilizáció által dominált Európában és Észak-Amerikában. A tartósnak tưnő stabilitás ezekben a nyugati típusú, gazdaságilag fejlett társadalmakban a biztonság utópiáját látszólag közelebb hozta a megvalósíthatósághoz. A szabályozott közösségi együttélés kereteinek állam általi szavatolása kvázi elaltatta a fejlett társadalmak éberségét. Az újabb vigilanciát a 20-21. század fordulóján Oszama bin Laden repülőgépei keltették fel, melyek úgy csaptak le a New York-i World Trade center tornyaira, mint derült égből a villám, és azóta is riadókészültségben tartják az USA-polgárokat. Majd a koncerteken, stadionokban, tömegrendezvényeken történő pokolgépes robbantások, utcai késes támadások, gyalogosok közé hajtó kamionok alapjaiban rengették meg a jóléti társadalmak biztonságérzetét, új fordulatot adva a biztonságról folyó már nemcsak filozófiai, szociológiai és politikai, hanem hétköznapi diskurzusnak is. Az angol Charlotte Heath-Kelly Halál és biztonság címü, 2016 novemberében megjelent legújabb könyve e témában már napjaink tapasztalatainak birtokában definiálja újra a megtépázott biztonság fogalmát. A szerző abból indul ki, hogy a profilaktikus diskurzus át kell, hogy adja a helyét a retrospektív diskurzusnak. Heath-Kelly véleménye szerint el kell fogadni, hogy új kockázatok dinamikájával terhelt világunkban a váratlan halált, sérülést, fájdalmat nem lehet a mindennapi életből kizárni, a katasztrófákat nem lehet óvintézkedésekkel megelőzni, csak a traumákat lehet kezelni - utólag. Vagyis a vágyott és remélt biztonság illúzió. Együtt kell élni a fenyegetettséggel, tudomásul kell venni a bizonytalanságot.

De vajon igaza van-e? Képes-e az ember lemondani a biztonságról, amelyhez ösztönösen ragaszkodik?

Aligha, hiszen a biztonság iránti akut szükségletet mindennapi nyelvhasználatunk is alátámasztja. Különféle jelzős szerkezetek, szintagmák utótagja, életünk legkülönbözőbb területeivel hozható összefüggésbe. Beszélünk nemzetbiztonságról, katonai biztonságról, létbiztonságról, közbiztonságról, közlekedés- (közúti és vasúti) biztonságról, jogbiztonságról, 
vagyonbiztonságról, bankbiztonságról, munkahelyi biztonságról, élelmiszerbiztonságról, informatikai biztonságról stb. De voltaképpen mi a biztonság? Hogyan definiálható?

A biztonság fogalomtörténeti vizsgálata az ókortól kezdve messzire vezetne, mint ahogy aktuális szociálpolitikai témákkal való kapcsolatainak elemzése is. A mindennapi nyelvhasználat evidenciaként kezeli, amelynek pontos körülhatárolását éppen ezért szükségtelennek tartja: mindenki tudja, miről beszélünk. Olyan értéknek tűnik, amely az egyén és a társadalom legfőbb prioritásai közé tartozik, és vagy konkretizálható materiális javakban testesül meg, mint pl. kiszámítható, tervezhető életkeretek, munka, egzisztencia, vagy megfoghatatlan, mint maga az élet, az egészség, a boldogság fenntartásának akarata. Nem más, mint a koincidenciák, a véletlenek maximális kiküszöbölésére törekvés, amelyek egyik pillanatról a másikra felforgathatják a legkiszámítottabb, legmegtervezettebb életeket is. A véletlenek szerepe azonban ambivalens, hiszen épp ezek hozhatják el a legboldogabb pillanatokat, a váratlan találkozásokat, új emberi kapcsolatokat, szerelmet, fordulatokat, nagy meglepetéseket az életben. A biztonságra törekvés ezért korlátja lehet a kockázatvállalásnak, vagy, ahogy az egzisztencializmus filozófiája tanította, az alternatívák közötti szabad választásnak. A biztonságunkat választva önként feladjuk a szabadságunkat.

A normatív szabályozások, kötelező jellegü előírások, a különféle kényszerek, amelyek a társadalomban élők egymás közti viszonyát szervezik, szabadságvesztést okoznak. A törvényeknek való alávetettség elfogadásáért az államvezetés az állam polgárainak fizikai biztonságot ígér. Egyszerüen fogalmazva, nem élhetek természetes jogommal a másik rovására, mint ahogy a másik sem az én rovásomra. A liberális politikai filozófia történetének ikonikus alakjai Thomas Hobbestól és John Locke-tól kezdve Wilhelm von Humboldtig lényegében alku-szituációként fogják fel a természetes jog és a biztonság közötti döntést. Két alapérték ütközéséről van szó: a természetes jogról való lemondásért az egyén a biztonság ígéretét kapja cserébe az államtól. A szabadság szorongása helyett a létbiztonságot. A jóléti társadalmak tartós sikere a 17. századtól kezdve ezen a „társadalmi szerződésen” alapul. Bár a „társadalmi szerződés” természetesen fikció, a valóságban sohasem köttetett meg az állam vezetése és polgárai között, tény, hogy a modern társadalom keretei között kiszámíthatóbb, tervezhetôbb lett az élet, csökkent a szorongás, nőtt a lét- és anyagi biztonság és nem utolsósorban a jogbiztonság. A törvények korlátozóak, azonban erga omnes hatályuknál fogva mégis demokratikusak. Ha mindenkit kötnek a szabályok, ha senki sem „egyenlőbb” a másiknál - orwelli értelemben -, akkor a korlátok nem korlátok többé, hanem önkéntes vállalások. Szabadság és biztonság történelmi harca utóbbi javára látszik eldőlni. A történelmi tapasztalatok szerint a forradalmi korszakok szabadságélményének eufóriája nem sokáig tudja kompenzálni az ezekben a helyzetekben szükségszerűen kialakuló létbizonytalanságot.

Fentiek magyarázatot adnak arra, hogy a fogalom politikai karrierje miért tarthat ki az ókortól kezdve máig. Azért, mert a modern közösségek által kivívott egyik legnagyobb értékről van szó, nagyobbról, mint maga a szabadság. Minden politikai erő a biztonság megteremtésével és megőrzésével, azaz a jelen befagyasztásával, a jövő időtlenítésével kampányol, a kockázatok kiküszöbölését ígéri a közösség tagjainak, akik erre vevők. Olyannyira, hogy például a jelenlegi közel-keleti konfliktusok során az életükért futó tömegektől való félelem az európai emberben felülírta a szolidaritást, az európai jólét és a szekularizáció féltése az iszlám fundamentalizmustól az emberséget. Az európai ember félelmében - átmenetileg - saját hagyományos, büszkén hangoztatott európai értékeit függesztette fel. Ortega y Gasset egy 1949-ben Berlinben tartott előadásában Európát még épp a stabilitással hozza összefüggésbe. Szerinte a világháborúk lezárulása után ez a kontinens elsősorban a biztonságot jelenti. Ez a mítosz nemcsak az európaiakban élhet, hanem más kontinensek lakóiban is, hiszen ez váltotta ki a 21. század második évtizedének közepén az újabb milliós népvándorlási hullámot. Ez viszont paradox módon átfordította a mítoszt az ellentétébe: úgy túnik, Európa ma a kiszámíthatatlanságot jelenti inkább a viszonylagos biztonságban. Az USA után az európai társadalom is elkezdett félni. Persze, nemcsak az idegenektől, a „migránsoktól”, hanem a hazai bűnözőktől is. Biztonsági zárakkal, 
térfigyelő kamerákkal, riasztó berendezésekkel védjük lakásainkat, a paprikaspray és esetleg a riasztó pisztoly városi túlélő felszerelésünk része.

Az említett példák azt mutatják, hogy a biztonságnak nemcsak filozófiai és politikai aspektusa van, hanem konkrét, védendő materiális értéke is. Azaz a biztonság nemcsak absztrakt érték, hanem szinte kézzelfogható: olyan, amely mérhető, akár pénzben is. A biztonság magában foglalja az élet és testi épség, a lakhatás, a jövedelem, az anyagi javak, a családtagok vagyonának biztonságát, az egészségügyi ellátás biztonságát és még sok mást. Ezért az egyén hajlandó áldozatot hozni, azaz nem tartja nagy árnak a fizetséget különféle adók, jövedelem-elvonások, járulékok formájában. A közbiztonság megteremtése és megőrzése nincs ingyen, csakúgy, mint ahogy a privát biztonságé, politikai és civil biztonságé, munkahelyi biztonságé, közúti biztonságé, informatikai biztonságé, élelmiszerbiztonságé stb. sincs. A biztonságnak tehát nemcsak értéke, hanem ára is van. Közhely, hogy a biztonság drága, de alapvető igazság, amelyet minden áldozat és károsult szó szerint a saját bőrén tapasztal meg, hogy a biztonság hiánya még drágább: az egyén testi épségébe, életébe kerülhet.

Biztonságról nemcsak filozófiai, szociológiai és politikai értelemben beszélhetünk tehát (a militáris, katonai értelmet itt teljes egészében mellőzzük, mert az extrém állapotra vonatkozó külön téma kell, hogy legyen), hanem pénzügyi és gazdasági értelemben is, noha ilyen mérések csak részlegesen és ellentmondásosan állnak rendelkezésre. A különböző nemzeti statisztikák és mérések, mint pl. a közúti balesetet szenvedett egyének anyagi és nem anyagi kárára, nemzetgazdasági értékére vonatkozóak, akkora eltéréseket mutatnak brit és német vizsgálatokban, hogy azokból objektív következtetéseket levonni nem lehet. A standardizálás hiánya nem teszi lehetővé a biztonság értékének nemzetközi összehasonlítását. Egyes nemzetek magasra taksálják az emberi életet, mások kevesebbre. Egyes nemzetek a nem materiális károkat is felszámítják, mások csak a konkrétan felmerülő kiadásokat. Pedig a kár meghatározásának, standardizálásának szükségessége a befektetés és megtérülés arányának kiszámíthatósága, a biztonsági kiadások tervezhetősége miatt egy-egy állam költségvetése szempontjából könnyen belátható. Ha alulkalkulálják a biztonsági kiadásokat, káresemény bekövetkezésekor a szükségesnél jóval nagyobb kompenzációs kiadások keletkeznek, ha viszont túlkalkulálják, akkor a téves allokáció más területekról von el - fölöslegesen - ott sokkal nélkülözhetetlenebb forrásokat az eleve limitált állami költségvetésből.

A biztonság definícióját tehát érdemes közgazdasági szemponttal is kiegészíteni.

Ha a biztonság filozófiai-szociológiai értelemben a véletlenek, koincidenciák, kockázatok maximális kiküszöbölésére, a jelen konzerválására és a jövő bizonytalanságainak kiiktatására való törekvést jelenti, akkor közgazdasági értelemben is ebből érdemes kiindulnunk. Mivel azonban itt még kevésbé absztrakt, sőt, kifejezetten konkrét, akár pénzben is mérhető értékről van szó, hasznos lehet igénybe vennünk az angol nyelv segítségét is, amely különbséget tesz az elvont érték és a konkrét, materializálható kiadás között. Az angol ugyanis több általam ismert nyelvtől eltérően nem egy szóval jelöli a biztonságot, mint például a magyar, a német (Sicherheit), francia (sécurite), olasz (sicurezza), orosz (bezopasnost'= veszélymentesség!), hanem kettővel: safety és security. Ez a két szó a nem angol anyanyelvűek számára szemantikailag nehezen szétválasztható, éppen azért, mert a legtöbb nyelvre egy szóval fordítják. Rokon fogalmak, de nem azonosak: a biztonság két aspektusát testesítik meg. A safety a biztonság állapotát, a fenyegetettségtől való mentességet (vö. orosz bezopasnost') jelenti, míg a security a védelmet, a veszélyek és fenyegetettség elhárítását. $\mathrm{Az}$ ipari létesítményeket, épületeket, repülőtereket, közintézményeket védő szolgáltatás neve „Security Service”, a computereket vírusoktól védő program neve „Security Check”, a veszélyt jelző programoké „Security Alarm”. Ezek védettséget szolgáltatnak, és mint szolgáltatásoknak áruk van. A safety ezzel szemben egy átfogóbb fogalom, a biztonságot, mint védettséget jelenti, amelyből a védelem (security) levezethető. A safety az állapot, a security az út, mely ehhez elvezet. Más szóval a safety a cél, a security az eszköz. Az előbbihez eszmei érték társul, az utóbbihoz anyagi. 
Horst Eintorf német közgazdász kézenfekvő definícióját kölcsönvéve így határozhatjuk meg legegyszerübben a biztonság fogalmát:

„A biztonság olyan események, fenyegetések és kockázatok hiányának állapotát jelenti, amelyek - közvetve vagy közvetlenül - kárt, fájdalmat vagy szenvedést okoznának.”(4.o.)

Ezen események, fenyegetések és kockázatok elhárításának anyagi vonzata van, amelynek volumenét a kár mértéke és a bekövetkezés valószínűsége együttesen határozza meg. Ilyen számítások természetesen régóta léteznek, hiszen ezen alapulnak a különféle élet-, vagyon-, baleset és egyéb biztositások. Âltalánosságban elmondható, hogy minél magasabb a jövedelmünk, minél magasabb az életszínvonalunk, annál nagyobb a fizetési hajlandóságunk, ha reális esélyt látunk annak garantálására.

Ez a tény kompatibilis azzal a megfigyeléssel, hogy a nyugati típusú ipari országok biztonsági standardja jóval magasabb, mint pl. a fejlődő országoké. Ezért a befektetések aránya is magasabb ott, ahol magasabb fokú a biztonság. Ez a megfigyelés a gazdasági mikroegységekre is igaz. Magas költségvetésü, fejlett technológiával dolgozó cégek jóval többet költenek biztonsági óvintézkedésekre, mint pl. a kis volumenű, vidéki, agrártevékenységet folytató családi vállalkozások. Persze, ez csak nagy általánosságban érvényes, mert egy olyan kiszámíthatatlan civilizációs kockázat, mint a fukushimai atomreaktor-robbanás vagy olyan természeti katasztrófák, mint a cunamik egy csapásra megváltoztathatják a preferenciákat és növelhetik a fizetési hajlandóságot. Az értékváltás lassan is bekövetkezhet. Pl. a közúti balesetek statisztikája fokozatosan meggyőzte a gépkocsi ipart arról, hogy a balesetek megelőzése érdekében a technológiai fejlesztést nem annyira a sebesség fokozása irányában kellene erőltetni, hanem inkább a járművek biztonságos kialakításába érdemes többet beruházni.

A biztonság ökonómiája a közösségi élet legkülönbözőbb területeit fogja át a munkahelyi védelemtől a bűnmegelőzésig. A biztonsági kiadásokat éppúgy a kereslet és kínálat piaci törvényei szabályozzák, mint bármely más szolgáltatáséit. Ha nagyobbnak érezzük a kockázatot és a védendő értéket, akkor többet vagyunk készek fizetni érte. A felmérések azonban azt mutatják, hogy míg saját biztonságunkra hajlandók vagyunk áldozni, másokéra nem feltétlenül, így elkerülhetetlen a piaci mozgásba való állami beavatkozás, azaz a törvényi kötelezés például a minimális felelősségbiztosításokra. A biztonság fogalma ezzel egy újabb, etikai aspektussal egészül ki. A biztosítást, amely a biztonság formális, intézményes „megvásárlása”, drágának tartjuk, ezért szeretnénk megspórolni. Hogy a biztosítással megszerezhető anyagi biztonságunkon nem érdemes spórolnunk, azt saját bőrünkön tapasztaljuk, hogy mások biztonságán nem, azt - ha a lelkiismeretünkön nem - a pénztárcánkon.

A biztosítás normatív implikációi a biztonság átfogó fogalmából vezethetők le. Míg a biztonság régi, patinás fogalom, mint mondtuk, már az ókori rétorok is kampányoltak vele, a biztosítás ehhez képest nagyon újkeletü. Bár Európában is régóta létezett, szédületes karrierjét és meghonosodását az európai jóléti társadalmak hétköznapi fogalomkészletében amerikai hatásra kezdte a 20. század második felében. A biztosítás egy szerződés, magyarán üzlet, melynek ára van. A biztonság ezzel szemben társadalmi érték, absztrakt programfogalom, amely sokféle kontextusban jelenik meg, de ritkán határolódik körül pontosan, mert zsigeri szinten magától értetődő. Már az antikvitástól kezdve népszerü retorikai fogás volt, majd a modern társadalmak egyik vezényszavává és egyik legfőbb értékévé vált, mint a szekularizált közösség utópikus válasza a transzcendencia elvesztésére és az ontológiai bizonytalanságra.

Azt mondtuk korábban, hogy a biztonság két aspektusát megtestesítő angol megfelelők közül a safety a cél, a security pedig az eszköz a cél eléréséhez. Csakhogy a safety olyan cél, amelyről tudván tudjuk, hogy elérhetetlen. A biztonság tehát egy soha meg nem valósuló, vágyott állapot, egy szóval utópia. És ebben az utópikus státuszában osztozik a modern európai társadalmak olyan értékfogalmaival, mint a szabadság, egyenlőség, igazságosság. A fogalom politikai népszerüsége paradox módon éppen ebből az utópikus 
jellegból adódik, és éppen ezért lehet a másik háromhoz hasonlóan az ókortól máig töretlenül attraktív. A biztonság a szabadsággal, az egyenlőséggel és az igazságossággal együtt ugyanis olyan, mint a csillagok Kant egén: irányt mutatnak, de elérhetetlenek. Örök, olthatatlan vágyat ébresztenek bennünk a megragadásukra...

\section{Irodalomjegyzék}

Gehlen, Arnold (1940, 1944, 1950, 1976, 2014): Der Mensch, seine Natur und seine Stellung in der Welt. Junker und Dünnhaupt, Berlin 1940. 3. Auflage. 1944. 4. Auflage. Athenäum-Verlag, Bonn 1950. 16. Auflage. AULA-Verlag, Wiebelsheim 2014.

Ortega y Gasset, José (1949, 1960, 2007): Elmélkedés Európáról, előadás Berlinben 1949-ben, először publikálva: 1960, magyarul 2007, Budapest, L' Harmattan Kiadó, 9-86. o. Csejtei Dezső és Juhász Anikó fordítása

Beck, Ulrich (1986): Risikogesellschaft - Auf dem Weg in eine andere Moderne, Suhrkamp V., Frankfurt /M.

Beck, Ulrich (2007): Weltrisikogesellschaft. Auf der Suche nach der verlorenen Sicherheit, Suhrkamp V., Frankfurt /M.

Hitzler, Ronald (1994): Man wehrt sich wieder : über das "neue" Bedürfnis nach Sicherheit und Ordnung. In: Liberal - Vierteljahreshefte für Politik und Kultur 36 (1994), 3, pp. 86-90. URN: http://nbnresolving.de/urn:nbn:de:0168-ssoar-57285

Entorf, Horst (2013): Der Wert der Sicherheit: Anmerkungen zur Ökonomie der Sicherheit

https://mpra.ub.uni-muenchen.de/49690/1/MPRA paper 49690.pdf

Entorf, Horst (2013) http://www.sifo-dialog.de/images/pdf/fachworkshopsicherheitsoekonomie/2_Entorf_Praesentation.pdf

Kaufmann, Franz-Xaver (1970, 2012): Sicherheit als soziologisches und sozialpolitisches Problem. Untersuchungen zu einer Wertidee hochdifferenzierter Gesellschaften (2012),Berlin: Lit (Zivile Sicherheit 4); 407 S.; unveränd. Nachdruck von 1973

Heath-Kelly, Charlotte (2016): Death and Security: Memory and Mortality at the Bombsite (Manchester University Press) 